\title{
The Effect of Catalyst Amount \& Reacters Comperative on Glycerol Conversion From Castrol Oil With Catalyst Of Pertamina Cracking Process Unit III Palembang
}

\author{
Kiagus Ahma Roni ${ }^{*}$, M. Andika Mandala Putra ${ }^{2}$, Netty Herawati ${ }^{3}$, \\ Mardwita $^{4}$, Rifdah $^{5}$, Heni Juniar ${ }^{6}$ \\ 1,2,3,4,5,6 Chemical Engineering, Faculty of Engineering, Muhammadiyah University of \\ Palembang \\ Email: ${ }^{1 *}$ kiagusaroni@gmail.com
}

\begin{abstract}
Transesterification of oil with alcohol produces glycerol and methyl esters (biodiesel). The reaction is influenced, among others, by the amount of catalyst and the ratio of oil and meth hanol reagents. This purpose of research to determine the effect of the amount of catalyst and the ratio of reagents on the conversion of glycerol. The experiment was carried out in a three-necked flask equipped with a stirrer and reverse cooling. In a threenecked flask, $150 \mathrm{ml}$ of castor oil was added, $0.375 \mathrm{ml}$ of $\mathrm{H}_{2} \mathrm{SO}_{4}$ was added, heated to a temperature of $65^{\circ} \mathrm{C}$. Then add $185 \mathrm{ml}$ of methanol and stir for 30 minutes. Then let stand 24 hours to form two layers. The bottom layer is glycerol. The transesterification process was continued by adding $100 \mathrm{ml}$ of glycerol in a mixture of methanol (variation $1: 2,1: 3,1: 4$ ) with RCC catalyst (variation 1.7gr;1.9gr;2.1gr;2.3gr ;2.5gr) The mixture was then stirred at $90 \mathrm{rpm}$ for 75 minutes. Based on the results of research conducted, the highest glycerol conversion value was in the amount of catalyst $2.1 \mathrm{~g}$ with a ratio of reagents between castor oil and methanol of $1: 3$ of $55.33 \%$.
\end{abstract}

Keywords: Amount of catalyst, Conversion, Glycerol, Transesterification

\section{INTRODUCTION}

Jatropha oil is a yellow liquid, has a characteristic odor, is tasteless and is not cloudy even if it is stored for a long time. Castor oil is different from other vegetable oils because it has a high specific gravity, viscosity, acetyl number, and solubility in alcohol. Castor oil is soluble in 95\% ethyl alcohol at room temperature and other polar organic solvents and slightly soluble in aliphatic hydrocarbons. The solubility of castor oil in petroleum ether is relatively low, which distinguishes it from other triglycerides. Jatropha oil is renewable, biodegradable, environmentally friendly, easy to obtain and economical, so it can be used as biofuel. [14]

The conventional method for producing biodiesel from castor oil and other types consists of several stages, namely oil extraction, purification and esterification or transesterification reactions, this process is a long process. This processing method consumes $70 \%$ of the total production cost if refined oil is used as raw material. The development of reactive extraction has the potential to 
reduce processing costs with any type of feedstock. Hybrid or simultaneous processes that combine reaction and separation processes is one thing that has received a lot of attention lately due to saving investment and energy costs and several other things. Reactive extraction is a process that involves reactions and separations carried out simultaneously. Phase separation can be carried out naturally in reactive systems by adding a solvent. Alcohol acts as a solvent in the extraction process and as a reagent in the transesterification reaction during reactive extraction. Based on the thoughts that have been described, the authors conducted research on the manufacture of jatropha oil biodiesel Jatropha curcas L.) using reactive extraction, so that this method can later be developed for industrial scale and is able to minimize environmental impacts. [7]

The consumption of glycerol in industry is very large. Glycerol is widely used as a raw material for the chemical, pharmaceutical and cosmetic industries . One of the products oleochemicals which are being much studied when it is biodiesel from oils of vegetable. However, the other product of this reaction has not received much attention, namely glycerol . In this study, the manufacture of glycerol from castor oil and methanol with used catalyst from the residue catalytic cracking process was carried out using variations in the number of catalysts and reaction ratios. Catalyst can be defined as a substance that can increase the rate of reaction to reach equilibrium with constant chemical conditions at the end of the process. [8]

In the research on the reaction kinetics of making biodiesel from used coconut oil, the conversion calculation is carried out by analyzing the glycerol content in the reaction product. The analysis of glycerol in the material can be carried out by the acetin method. [10]

Glycerol is a trihydroxy alcohol which comprises the top three atoms of carbon. So, each carbon atom has an $-\mathrm{OH}$ group. Glycerol is a molecule bidrofilik relatively small and easily in the paste between 8 chain protein and form a bond of hydrogen with a group and the protein gluten. It 's resulted in a decrease in the interaction of direct and closeness between the chains of proteins. In addition to that, the rate of transmission of vapors of water passing through the film gluten which reported increases in line with the increase in levels of glycerol in the film as a result of a decrease in the density of the type of protein. [8]

Glycerol $\left(\mathrm{C}_{3} \mathrm{H}_{8} \mathrm{O}_{3}\right)$ has the name of the chemical 1, 2.3 -propanetriol or tribydroxypropane and have the name of trade glycerin. Glycerol is a by- product of biodiesel production from transesterification. Glycerol (1 , 2,3, propanetriol ) is something that is not color, no smell, and the fluid viscous that has taste sweet. [1]

In this transesterification reaction, methanol or ethanol can be used as a reactant. In this process, methanol was chosen as the reactant because it is the most reactive alcohol. The transesterification reaction is a reversible reaction. Due to its reversible nature, the reaction shift to the right (towards the product) is 
usually carried out by using an excess of alcohol from the stoichiometric equilibrium. [3]

The ability of chemical compounds to catalyze chemical reactions is measured from the activity of the catalyst which is usually expressed in the percentage of conversion or the number of products produced from the amount of reactants used in a certain reaction time. [4]

Glycerol is soluble in water and insoluble in ether. In addition, glycerol is also useful for the synthesis of fat in the body. Glycerol is obtained from the hydrolysis of a fat or oil. [6]

The transesterification reaction between oil and monohydrate alcohol (methanol or alcohol) will produce another ester (biodiesel) and glycerol. Exchange of the alcohol portion of an oil/fat ester can be accomplished in an acidic or basic solution by a reversible reaction between the ester and the alcohol. This transesterification reaction is directly analogous to hydrolysis in acids or bases. Because the reaction is reversible, it is common to overuse the initial alcohol. In this case a base is used or as a catalyst not as a reagent. The operating conditions in this process can be carried out at high temperatures above $150^{\circ} \mathrm{C}$. Can also be done on medium temperature $100-130^{\circ} \mathrm{C}$. If a low temperature between $50-80^{\circ} \mathrm{C}$ is used, a catalyst can be used. Catalysts that can be used include acids, bases and ion exchange compounds. Meanwhile, for even lower temperatures of $30-50^{\circ} \mathrm{C}$, enzymes need to be added to speed up the reaction. [3]

Catalysts are usually used to increase the reaction rate and yield. Theoretically, the transesterification reaction is an equilibrium reaction. In this reaction a large amount of alcohol is used to direct the equilibrium reaction to the right and produce high amounts of methyl ester, the desired end product. [13]

Catalysts that can be used in the manufacture of biodiesel with glycerol as a by-product are acids, bases and ion exchangers. The relationship of catalyst efficiency with acid or bad strength is very important and has been studied by many researchers. The base catalyst will react with one of the reactants (protolytic reacton) that is added to form an ion that has a charge. These charged ions will not act as a catalyst and are generally stronger than normal. [12]

Catalysts can be divided into two main groups: homogeneous catalysts and heterogeneous catalysts. Heterogeneous catalysts are catalysts that are in a different phase from the reactants in the reaction they catalyze, while homogeneous catalysts are in the same phase. A simple example of heterogeneous catalysis is that the catalyst provides a surface on which the reactants (or substrates) are temporarily adsorbed. The bonds in the substrates become weak enough to allow for the formation of new products. The bond between the product and the catalyst is weaker, so it is eventually released. Homogeneous catalysts generally react with one or more reagents to form a chemical intermediate which then reacts to form the final reaction product, in a 
process that recovers the catalyst. The following is a general schematic of a catalytic reaction, where $\mathrm{C}$ represents the catalyst:

$$
\begin{aligned}
& \mathrm{A}+\mathrm{C} \rightarrow \mathrm{AC} \\
& \mathrm{B}+\mathrm{AC} \rightarrow \mathrm{AB}+\mathrm{C}
\end{aligned}
$$

Although the catalyst $(C)$ is consumed by reaction 1 , it is then regenerated by reaction 2 , so that for the overall reaction to be, the catalyst is neither eaten nor created. [12]

$$
\mathrm{A}+\mathrm{B}+\mathrm{C} \rightarrow \mathrm{AB}+\mathrm{C}
$$

The greater the amount of base catalyst used in the transesterification reaction in the manufacture of methyl esters, it will cause the amount of methyl ester produced to decrease. This is caused by the overreaction of the catalyst with triglycerides that form soap and produce more by-products such as glycerol. The formation of soap can be seen from the results of the transesterification which is cloudy in the sample with a higher amount of catalyst [11].

The ability of a chemical compound to catalyze a chemical reaction is measured by the activity of the catalyst which is usually expressed in the percentage of conversion or the number of products produced from the amount of reactants used in a certain reaction time [4]. The catalyst has a service life. The service life of the catalyst or the life of the catalyst can be defined as the period during which the catalyst can produce the desired product with results that are not much different from the initial conditions. The service life or service time of the catalyst is strongly influenced by the type of reactant used, in addition to the pressure and temperature used in the process [4] . Repeated use of the catalyst will cause the activity of the catalyst to decrease (deactivation occurs).

The occurrence of this deactivation is certainly a process that is not economically profitable so its effects must be minimized. In most catalysts, the activity of the catalyst will drop sharply at the start of the process and will then reach a state where the decline in catalyst activity slows down with time. Some of the causes of a decrease in catalyst activity are the occurrence of fouling on the surface of the catalyst, the occurrence of catalyst poisoning (poisoning), the occurrence of clumping (sintering) [6].

From the research reference [2], the glycerol conversion to be carried out is different in the catalyst used, namely the RCC (Residue Catalytic Cracking) catalyst of the crystalline Zeolite type, namely from the waste of the Pertamina Petroleum Cracking process. This catalyst waste is used in an oil refinery equipped with RCC as a material to direct and accelerate the reaction rate of the desired main products such as: LPG (Elpiji), Propylene, Polygasoline, Naptha, LCD (diesel base material) and Decant Oil (fuel base material). oils), the effect of the use of this waste catalyst affects the increase in glyceride conversion with an increase in the percentage of catalyst, because more and more reactants are activated, so the collisions that occur are getting bigger. [11]. 
Until now, research on catalyst waste has been carried out, including [14] :

1. According to research conducted in America and Australia, (Construction Magazine, No: 253 - June, 1997) the catalyst waste produced by RCC is not categorized as toxic hazardous waste (B3). Because the waste catalyst is not dangerous and quite safe, it can be used as a mixture in the manufacture of concrete or ceramics.

2. According to research conducted in America and Australia, (Construction Magazine, No: 253 - June, 1997) the catalyst waste produced by RCC is not categorized as toxic hazardous waste (B3). The $\mathrm{pH}$ measurement results show that the used catalyst in $\mathrm{CaCb}$ is only $3.96-4.80$ until it is non-corrosive.

3. According to the results of the TCLP (Toxicity Characteristic Leaching Procedure) analysis, the catalyst waste has metals below the specified quality standards, so they are safer for the environment. Based on this, the used catalyst cannot be classified as B3 waste. Because it does not meet the chemical classification characteristics test.

4. In addition to the use of waste catalysts for ceramics production, several researches on making ceramics have also been carried out using other mixed materials such as fly ash, Crom waste from leather tanning and various other mixed materials. Because the catalyst waste is harmless and quite safe, it can be used as a mixture to produce building materials and ceramic products. The process of making these products is done by mixing several ingredients in the ratio: sand: $64 \%$, catalyst waste: $16 \%$, cement: $20 \%$, with additional water for mixing. 2.4 Methanol Methanol is an alcohol with the shortest carbon chain and is polar. So that it can react more quickly with fatty acids, it can dissolve all types of catalysts (both alkaline and acid) and is more economical. One of the materials used in the transesterification process is methanol. Methanol, also known as methyl alcohol, is the simplest compound of the alcohol group. Its chemical formula is $\mathrm{CH} 3 \mathrm{OH}$. Methanol is a colorless, volatile liquid. Methanol has a molecular weight of 32,042, a melting point of $-98 \mathrm{oC}$ and a boiling point of $64 \mathrm{oC}$. In general, methanol is used in the transesterification process because methanol is cheaper and easier to convert.

\section{METHODS}

In research is carried out in the laboratory of Engineering Chemistry Faculty of engineering universities muha mmadiyah Palembang. The tools used are Beacker Glass, Buret and stative, cup Porcelain, Erlenmeyer, measuring cup, Hot Plate, conderser, Leg three, flask, Magnetic Stirer, Pipette drops, Spatula, Scales 
Electric, thermometer, pycnometer, Viscometer. The materials used are oils Distance, methanol , $\mathrm{NaOH}, \mathrm{HCl}$, Acid Acetate Glacial, Catalysts (PRC), Aquadest, indicators PP, Sodium Acetate.

In this research, the manufacture of glycerol is done through two steps reactions, the reaction esterifika the castor oil with methanol using a catalyst $\mathrm{H}_{2} \mathrm{SO}_{4}$ to remove the fatty acid -free, and the reaction transesterifikas $\mathrm{i}$ oils distance methanol using a catalyst $\mathrm{KOH}$ [10]. In this research, the catalyst used was a crystalline zeolite type RCC (Residu Catalytic Cracking) catalyst.

\section{Esterification Reaction Stage}

Castor oil $150 \mathrm{ml}$ three neck flask was added then added $\mathrm{H}_{2} \mathrm{SO}_{4}$ concentrated as much as $0.375 \mathrm{ml}(0.25 \mathrm{wt} \%$ oil $)$, then heated to a temperature of $60^{\circ} \mathrm{C}$. Methanol was added as $185 \mathrm{ml}$ Erlenmeyer flask that was equipped cooling behind later heated until it reaches its boiling point of $64.7^{\circ} \mathrm{C}$. Then the methanol is fed into the stirred reactor through the return cooling channel. The temperature in the reactor is maintained at $60^{\circ} \mathrm{C}$ for 30 minutes. After 30 minutes the reaction was stopped and then put into a separating funnel and allowed to stand until it reached room temperature (left for 24 hours). There are 2 layers, namely the top of the biodiesel and the bottom of the glycerol.[3]

\section{Transesterification Reaction Stage}

$1.7 \mathrm{~g}$ of RCC catalyst was dissolved with $200 \mathrm{ml}$ of methanol into a beaker and stirred with a magnetic stirrer. $100 \mathrm{ml}$ of oil was put into a glass beaker containing methanol-RCC. The mixture was then stirred with a magnetic stirrer at $90 \mathrm{rpm}$ for 75 minutes. The mixture was allowed to stand for 24 hours. The same process was carried out for variations in the amount of RCC catalyst, namely $1,9: 2,1: 2,3: 2,5$. and the ratio of reagents $1: 2,1: 3,1: 4$. The reaction mixture obtained was filtered using filter paper to separate the RCC catalyst. The reaction mixture was put into vacuum distillation to separate the methanol. After the ester and glycerol formed into 2 layers, the distillation was stopped. The bottom layer is glycerol and the top layer is ester and residual oil.[5]

\section{Analysis Of Results}

Weighing $1.5 \mathrm{~g}$ of glycerol then put into a $250 \mathrm{~mL}$ erlenmeyer, and added 3 grams of sodium acetate and $7.5 \mathrm{~mL}$ of acetic anhydride, then boiled for 1 hour. Furthermore, the mixture reaches approximately $80^{\circ} \mathrm{C}$, the addition of $50 \mathrm{ml}$ of distilled water at a temperature of $80^{\circ} \mathrm{C}$ through a back funnel. After that it was fused to room temperature, removable cooling back, then added $2 \mathrm{~mL}$ of phenolphthalein indicator. After that, the liquid was neutralized with $6 \mathrm{~N} \mathrm{NaOH}$ solution, a pink color appeared, then $10 \mathrm{~mL}$ of $1 \mathrm{~N} \mathrm{NaOH}$ solution was added. After the cooling was installed, the mixture was boiled again for 15 minutes. the liquid as soon as possible and then titrated with $0.5 \mathrm{~N} \mathrm{HC1}$ until the pink color disappears. Then the volume of HC1 used for the titration is recorded. In addition, a blank titration was carried out in the same way, but without samples. 
Then HC1 for analysis was also recorded. The amount of free glycerol at the end of the reaction is expressed by the equation:

$\mathrm{G}=\frac{\mathrm{W} 1 \mathrm{~W} 3}{W 2 W 4} \times\left(\mathrm{V}_{\mathrm{b}}-\mathrm{V}_{\mathrm{s}}\right) \mathrm{N}_{\mathrm{HCl}}$

Because the weight of the mixture and the weight of the sample are the same, the equation becomes:

$\mathrm{G}=\frac{\mathrm{W} 3}{\mathrm{~W} 4} \mathrm{x}\left(\mathrm{V}_{\mathrm{b}}-\mathrm{V}_{\mathrm{s}}\right) \mathrm{N}_{\mathrm{HCl}}$

Where $G$ is the amount of glycerol produced (mgrek), W1 is the weight of the mixture (gr), W2 is the weight of the sample taken (gr), W3 is the weight of glycerol after heating (gr), W4 is the weight of glycerol after analysis (gr), V b is the titration volume of $\mathrm{HCl}$ blank $(\mathrm{ml}), \mathrm{V} s$ is the volume of the titrated $\mathrm{HCl}$ sample $(\mathrm{ml}), \mathrm{N} \mathrm{HCl}$ is the normality of the $\mathrm{HCl}$ solution (mgrek/l)

Conversion $(\mathrm{Xm})$ is calculated by the equation:

$\mathrm{Xm}=\frac{\mathrm{G}}{\mathrm{G} 0}$

where $G 0$ is the initial total glycerol (mgrek). $G_{0}$ is the product of the total fatty acid equivalent (mgrek/gr) by the weight of the oil (gr). [9]

\section{Determination of total fatty acid equivalent (EALT)}

Glycerol esterified as much as $5 \mathrm{gr}$ was put into Erlenmeyer then added $50 \mathrm{ml}$ of $0.5 \mathrm{~N} \mathrm{NaOH}$ and then heated for 30 minutes. Furthermore, after being cooled this solution was added 3 drops of pp indicator and titrated with $0.5 \mathrm{~N} \mathrm{HCl}$ solution until the color changed to clear.

EALT $=\frac{(\text { V blank }-\mathrm{V} \text { titration })}{\text { M glycerol }} \times \mathrm{N}_{\mathrm{HCl}}$

Where EALT is the total fatty acid equivalent ( $\mathrm{mg} / \mathrm{gram}), \mathrm{V}$ blank is the volume of the $\mathrm{HCl}$ titration blank ( $\mathrm{ml}$ ), $\mathrm{V}$ titration is the volume of the $\mathrm{HCl}$ sample being titrated (ml), and $\mathrm{N} \mathrm{HCl}$ is the normality of $\mathrm{HCl}$ (grek/L). [12]

\section{RESULTS AND DISCUSSION}

Based on the research that has been conducted by researchers previously ( Yustia Wulandari and Meilani Kusuma 2004 ), The effect of the addition of the volume of methanol to the levels of glycerol that is generated in the crude glycerol, namely, that the concentration of glycerol increases in line with the increase in the volume of methanol. 


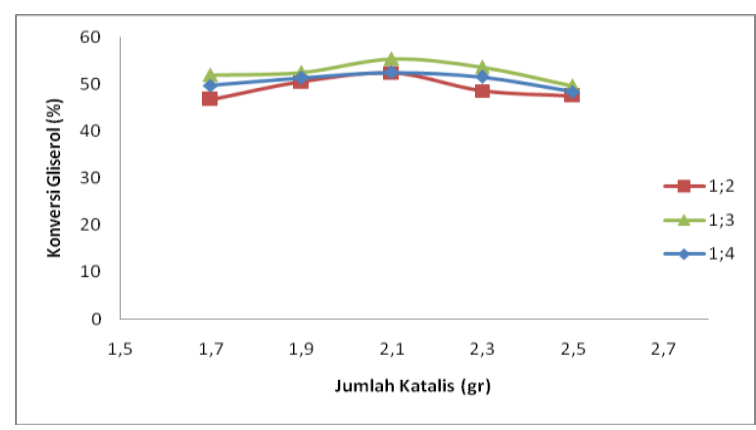

Figure 1. Glycerol Conversion Results based on variations in the ratio of reagents to the amount of catalyst

Based on these results, the stirring time and the amount of catalyst affect the glycerol content obtained. From the data above, it can be seen that the greatest increase in glycerol conversion occurred at a 1:3 ratio of reagents. As for the variation in the amount of catalyst, in this study the most optimum amount of catalyst was found in the amount of catalyst 2.1 grams, the glycerol conversion value produced was $55.33 \%$.

On the amount of catalyst between $1,7 \mathrm{gr}-2,1$ on the reaction ratio of $1: 2$ between castor oil and glycerol methanol conversion value increased se how a row is $46.75 ; 50.45$; and 52.33 . Meanwhile, at 2.3gr and 2.5gr catalysts, the glycerol conversion decreased again, respectively, to 48.55 and 47.45. [8]

Furthermore, at the amount of catalyst between $1.7 \mathrm{gr}-2.1 \mathrm{gr}$ at a $1: 3$ reaction ratio between castor oil and methanol, the glycerol conversion value increased successively 51.94; 52.48 and 55.33 . Meanwhile, at 2.3gr and 2.5gr catalyst, the glycerol conversion decreased again, respectively, to 53.56 and 49.55 . The larger the reaction ratio causes the glycerol conversion to increase. [8]

Likewise, the amount of catalyst between $1.7 \mathrm{gr}-2.1 \mathrm{gr}$ at a 1:4 reaction ratio between castor oil and methanol, the glycerol conversion value increased, respectively, which was 49.69; $51.33 ; 52.47$. Meanwhile, the glycerol conversion catalyst decreased again, respectively, at 51.47 and 48.35 . The glycerol content then decreases again at the 1:4 increase point because of the same polarity, causing the conversion of glycerol to the volume of crude glycerol to decreas. [5]

\section{CONCLUSION}

Based on the data that has been obtained, it is concluded that in the variation of the ratio of reagents to the amount of RCC catalyst, the largest conversion is $55.33 \%$ under optimum conditions at 1:3 ratio of reagents and 2.1 grams of catalyst. 
(Civil Engineeering, Elektrical Engineeering and Industrial Engineeering) Vol. 18, No : 2, 0 ktober 2021, p-ISSN:1907-5243, e-ISSN: 2655-8416

\section{REFERENCES}

[1] Ahmad Roni, K. (2016). Alkoholis Minyak Goreng Bekas (Jelantah) Pada Tekanan Lebih Dari Satu Atmosfer Dengan Katalisator Buangan Proses Perekahan Minyak Bumi Unit III Palembang. Jurnal Redoks, 1(1), 1-9.

[2] Aziz, I., Nurbayti, S., \& Rahman, A. (2012). Penggunaan Zeolit Alam sebagai Katalis dalam Pembuatan Biodiesel. Jurnal Kimia VALENSI, 2(4), 511-515. https://doi.org/10.15408/jkv.v2i4.268

[3] Djenar, N, S., \& Lintang, N. (2012). Esterifikasi minyak kemiri sunan (. Bionatura-Jurnal Ilmu-Ilmu Hayati Dan Fisik, 14(3), 229-235.

[4] Lestari, D. Y. (2011). KAJIAN TENTANG DEAKTIVASI KATALIS Dewi Yuanita Lestari Jurusan Pendidikan Kimia UNY Abstrak. Prosiding Seminar Nasional MIP A, 1-7.

[5] Octavia, R. Z. (2011). PEMBUATAN DAN UJI KUALITAS BAHAN $B A K A R D A R I M I N Y A K$ KELAPA (Cocos nucifera) FAKULTAS SAINS DAN TEKNOLOGI UNIVERSITAS ISLAM NEGERI (UIN) ALAUDDIN MAKASS AR. 1-82.

[6] Padil, P., Wahyuningsih, S., \& Awaluddin, A. (2012). Pembuatan Biodiesel dari Minyak Kelapa melalui Reaksi Metanolisis Menggunakan Katalis CaCO3 yang dipijarkan. Jurnal Natur Indonesia, 13(1), 27. https://doi.org/10.31258/jnat.13.1.27-32

[7] Putri, R. A., Muhammad, A., \& Ishak, I. (2018). Optimasi Proses Pembuatan Biodiesel Biji Jarak Pagar (Jatropha Curcas L.) Melalui Proses Ekstraksi Reaktif. Jurnal Teknologi Kimia Unimal, 6(2), 16. https:/ / doi.org/10.29103/jtku.v6i2.472

[8] Putri, S. K., Sudiyo, R., Studi, P., Pangan, T., Pertanian, P., Andalas, U., Kimia, J. T., Teknik, F., \& Mada, U. G. (2013). Studi Proses Pembuatan Biodiesel dari Minyak Kelapa (Coconut Oil) dengan Bantuan Gelombang Ultrasonik. Jurnal Rekayasa Proses, 6(1), 20-25. https:/ /doi.org/10.22146/jrekpros.2453

[9] Ristianingsih, Y., Hidayah, N., \& Sari, F. W. (2016). Pembuatan Biodiesel Dari Crude Palm Oil (Cpo) Sebagai Bahan Bakar Alternatif Melalui Proses Transesterifikasi Langsung. Jurnal Teknologi Agro-Industri, 2(1), 38. https://doi.org/10.34128/jtai.v2i1.23

[10] Roni, K. A. (2012). Pembuatan Biodiesel Biji Kepuh (Sterculia foetida L.) denganproses alkoholisis dengan katalisator buangan proses perengkahan minyak bumi pertamina unit II Palembang. Jurnal Dinamika Penelitian Industri, 23(1), 21-29. https://media.neliti.com/media/publications/79341ID-pembuatan-biodiesel-biji-kepuh-sterculia.pdf

[11] Roni, K. A., Dewi, A., \& Karim, M. A. (2019). Biodiesel from Jelantah oil with catalyst FCCu base chemical $\mathrm{Al} 2 \mathrm{O} 3$ based speed of statement and comparison of reaction. Journal of Computational and Theoretical Nanoscience, 16(7), 2914-2925. https://doi.org/10.1166/jctn.2019.8195

[12] Roni, K. ahmad, Agra, ida bagus, \& Sulistyo, H. (1998). Alkoholisis minyak biji kepub (sterculia foetida l.) Pada tekanan lebih dari satu atmosfer dengan 
(Civil Engineeering, Elektrical Engineeering and Industrial Engineeering) Vol. 18, No : 2, O ktober 2021, p-ISSN:1907-5243, e-ISSN: 2655-8416

katalisator buangan proses perengkahan minyak bumi Pertamina unit II Palembang (pp. 233-246).

[13] Santoso, H., Kristianto, I., \& Setyadi, A. (2013). Pembuatan Biodiesel Menggunakan Katalis Basa Heterogen Berbahan Dasar Kulit Telur. Disusun Oleh: Herry Santoso, ST, MTM, PhD Ivan Kristianto Aris Setyadi Lembaga Penelitian Dan Pengabdian Kepada Masyarakat Universitas Katolik Prahayangan, 1-29.

[14] Yolanda, T. (2018). CATALYTIC CRACKING MINYAK JARAKPAGAR (Jatropa curcas L) MENGGUNAKAN KATALIS ZEOLIT ALAM. 